\title{
Hepatitis E: A newcomer to the hepatitis alphabet - Case report and review of the literature
}

\author{
Karl Weiss mD, Louise Poirier mD, Sylvain VARIN mD, ClaiRe BeliVeau mD, Michel LaVerdière mD
}

\begin{abstract}
K Weiss, L Poirier, S Varin, C Beliveau, M Laverdière. Hepatitis E: A newcomer to the hepatitis alphabet - Case report and review of the literature. Can J Infect Dis 1995:6(1):34-37. The first Canadian case of hepatitis $E$ is described in a patient who travelled to Asia for a six-month period and spent most of his time in India. Hepatitis $E$ shares some similarities with hepatitis A, notably the mode of transmission and the absence of chronic course. However, a few important differences have been noted, including a higher mortality rate and a high fatality rate in pregnant women. Hepatitis $E$ is very common in developing countries and should be suspected more often in individuals with gastrointestinal complaints returning from endemic areas.
\end{abstract}

Key Words: Hepatitis E

\section{L'hépatite E : Un nouveau venu dans l'alphabet des hépatites}

RÉSUMÉ : Nous décrivons dans cet article le premier cas confirmé d'hépatite $E$ chez un patient revenant d'un voyage en Asie. L'hépatite $E$ présente de nombreuses similarités avec l'hépatite $A$, notamment son mode de transmission et l'absence d'un état de porteur chronique. Néanmoins, il existe quelques différences, entre autre un taux de mortalité plus élevé de façon générale et une sévérité marquée de la maladie chez la femme enceinte. L'hépatite $E$ est une pathologie très fréquente dans les pays en voie de développement et doit être recherchée chez les individus retournant de zones endémiques.

A 35-YEAR-Old CAuCASIAN MALE PRESENTED to THE travel clinic of the authors' hospital (Clinique des maladies tropicales, Hôpital Maisonneuve-Rosemont, Montréal) in June 1993, complaining of' abdominal pain, diarrhea and jaundice. He was returning from a six-month vacation in Asia, having spent most of his time in India. The patient's symptoms started 10 days after his return. While in India, the pa- tient was tattooed on his thighs, and he lived in suboptimal conditions. He drank nonbottled water, ate a variety of uncooked foods and was repeatedly subjected to potentially contaminated water (river water) in his daily hygiene. The patient was a nurse, had no particular medical history, was an occasional smoker and did not drink alcohol. When ques- 
tioned, the patient was ambivalent regarding his sexual orientation and denied any drug use. Before leaving for Asia, the patient went to a different travel clinic where he received all the appropriate immunizations (human gamma globulins, typhoid vaccine, diphtheria-tetanus:d2T5). During his trip, the patient did not take any medication. He was previously immunized against hepatitis $B$ due to his occupation and had no history of liver disease. Physical examination was normal except for jaundice and mild right upper quadrant tenderness. Blood tests revealed abnormal liver functions (Table 1), and a moderate amount of bilirubin was detected in the urinalysis. Abdominal ultrasound was normal except for a moderately thickened gallbladder. No hepatomegaly was seen. Serologies for hepatitis A (immunoglobulin [lg]M antihepatitis A virus [HAV]), hepatitis B (hepatitis B surface antigen, IgM antihepatitis B core antigen), hepatitis C (HCV) (anti-HCV), antihuman immunodeficiency virus and IgM anticytomegalovirus were negative. Serum was collected in June 1993 for hepatitis E antibody detection. The test was performed at the Centers for Disease Control and Prevention in Atlanta, Georgia by a microplate ELISA method using a recombinant antigen made on the premises (personal communication). The test was positive. At a follow-up visit in July, the patient was no longer experiencing his original discomfort and liver function was back to normal. This is, to our knowledge, the first confirmed case of hepatitis $\mathrm{E}$ diagnosed in Canada.

\section{REVIEW OF THE LITERATURE}

Hepatitis $E$ is a rarely encountered type of hepatitis in the western world. The first documented outbreak of hepatitis $E$ (diagnosed retrospectively) occurred in India in 1955 (1); it was supposedly related to the ingestion of contaminated water and resulted in over 50,000 cases. Since then, more incidences were documented of what was previously called 'enterically acquired non-A non-B hepatitis'. The virus associated with hepatitis $\mathrm{E}$ was isolated in 1989 by Krawczynski and Bradley (2,3). It is a nonenveloped virus of 27 to $34 \mathrm{~nm}$ (3) consisting of a single-stranded, positive-sense RNA molecule (4). Morphologically, hepatitis E virus (HEV) has some similarities with caliciviruses (5), but molecular characterization shows significant differences; the final taxonomic classification of' HEV is still unclear. During the past two decades, many outbreaks have been described in several countries, but India remains a region where this type of hepatitis seems to be highly prevalent (6-9), probably largely due to water contamination. Other countries where cases have been described include: Turkey (10), Ethiopia (11), Sudan (12), Egypt (13), Morocco (14), Algeria, Tunisia and Bangladesh (15), Burma, Pakistan and China (16), the former USSR (17), Mexico (18), Senegal (19) and Ivory Coast (19) (Figure 1). As more information on the disease incidence and distribution becomes available, it appears that hepatitis $E$ is a major cause of hepatitis in developing countries, if not the most common cause in adults (5).

In the western world, the disease has always been related to travelling to endemic areas. In the United States, four cases were confirmed by serology between 1989 and 1992
TABLE 1

Laboratory values

\begin{tabular}{lccc}
\hline & \multicolumn{2}{c}{ Results } & Normal range \\
& June 8, 1993 & $\begin{array}{c}\text { July 27, } \\
\text { of values }\end{array}$ & \\
\hline AST $(\mathrm{U} / \mathrm{L})$ & 615 & 24 & $0-40$ \\
ALT $(\mathrm{U} / \mathrm{L})$ & 1245 & 41 & $0-40$ \\
Total bilirubin & 126 & 32 & $0-21$ \\
$\quad(\mu \mathrm{mol} / \mathrm{L})$ & & & \\
Creatinine $(\mu \mathrm{mol} / \mathrm{L})$ & 74 & & $80-120$ \\
BUN $(\mu \mathrm{mol} / \mathrm{L})$ & 4.3 & & $2.5-7.1$ \\
\hline ALT & & &
\end{tabular}

ALT Alanine aminotransferase; AST Aspartate aminotransferase; BUN Blood urea nitrogen

(20): one patient acquired hepatitis in Mexico and the other three on the Indian subcontinent. Imported cases have also been reported in Europe, notably in the United Kingdom (21), the Netherlands (22) and Spain (23). The transmission of' HEV is very similar to that of HAV. The incubation period ranges from two to nine weeks, with a mean of 45 days (20). A fecaloral route has been implicated and proved by the virus being transmitted to a volunteer (24). HEV is not transmitted vertically (25), and there are no chronic carriers. Person to person transmission by casual contact is still controversial $(7,26)$. Hepatitis $E$ symptoms are similar to those of hepatitis $A$, but a few differences can be observed. First, the mortality rate seems to be higher -1 to $2 \%$ overall -10 -fold greater than that for HAV. The attack rate is highest among young adults 15 to 40 years old, who for the most part are already anti-HAV-positive. Aside from a few outbreaks $(7,27)$, it is a relatively uncommon condition in children. Another particular finding is that HEV causes severe disease in pregnant women, with a fatality rate reaching $25 \%$ in certain studies $(11,16)$, the peak occurring in the third trimester. Why hepatitis $E$ is responsible for such mortality during pregnancy remains unknown. Since viral hepatitis is the most common cause of jaundice in pregnant women in North America, it is important to remember that hepatitis $\mathrm{E}$ has a significantly different clinical course in pregnant patients (28).

Diagnostic tests have recently been developed but are still not easily available for routine testing in North America. Krawczynski and Bradley (2) were the first to use a fluorescent antibody blocking assay for HEV antibodies in serum. However, an important drawback of the test was inability to differentiate between past and present infection. An HEV ELISA has since been developed at Genelabs Technologies Inc (California) (27), using antigens derived from ORF2 and ORF3 of the Burma and Mexico strains. Acute phase sera were collected during outbreaks in India, Pakistan and Mexico and tested positive with the HEV ELISA. The test was used to document cases in the United Kingdom and in an epidemiological survey of hepatitis E in Hong Kong (29). Finally, a Western blot assay for hepatitis $E$ antibodies served as a laboratory tool in a Sudanese outbreak (12). All these tests performed fairly well and were able in some instances to differentiate between IgM and IgG antibodies. While more data are accumulated on their sensitivities and specificities (27), these tests could 


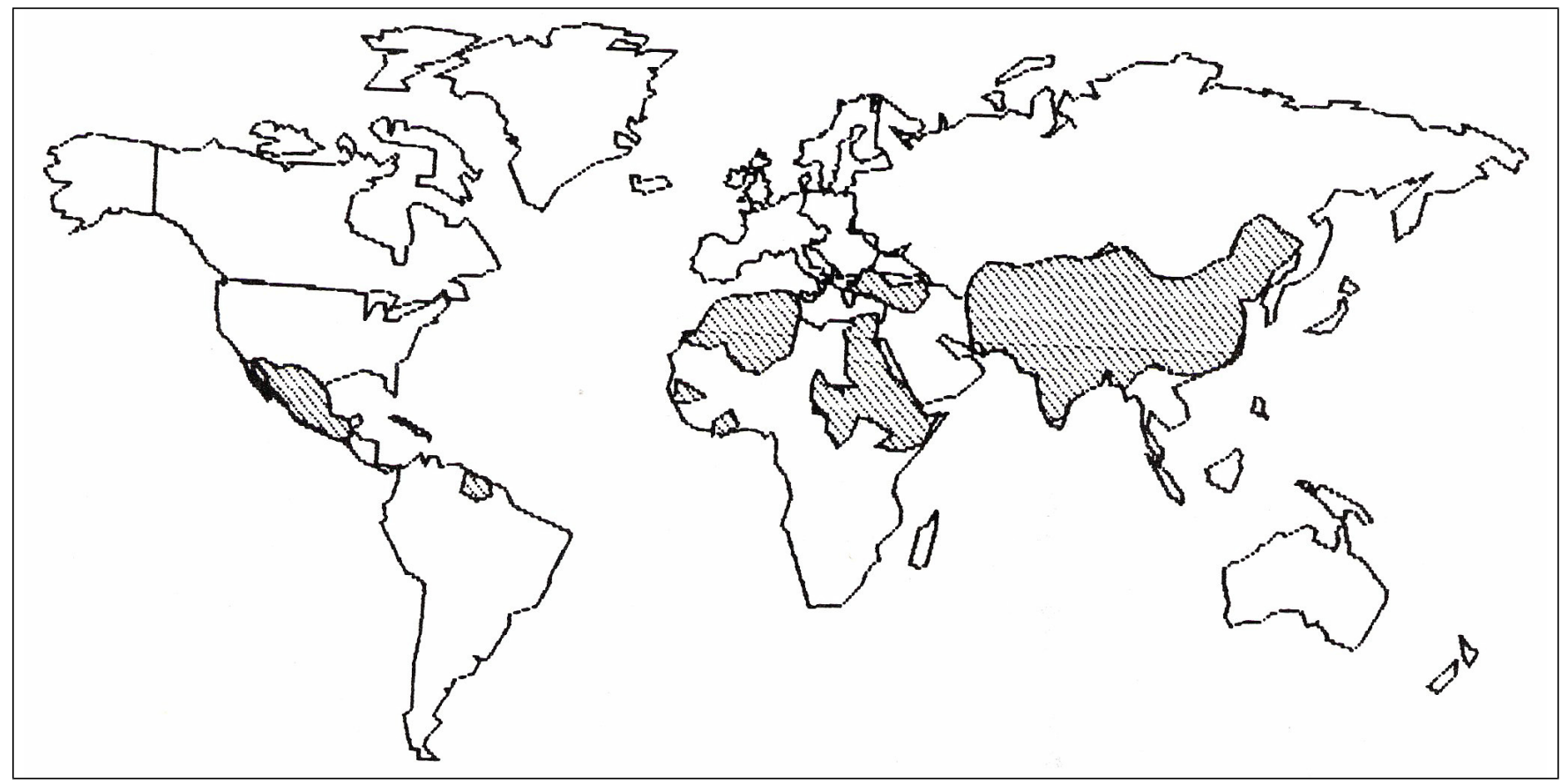

Figure 1) Regions where cases of hepatitis $E$ have been confirmed (shaded areas)

be available in the near future for routine serology.

Treatment of hepatitis $E$ is mainly supportive, and, as with other types of hepatitis, prolonged prothrombin time, hypoglycemia and altered mental status at admission are ominous signs. There is no vaccine available, and an Indian study failed to prove any protective effect of immune serum globulin from an Indian source as prophylaxis (26). Hepatitis $E$ is rarely encountered in Canada; nevertheless, it should be suspected in any traveller returning from a developing country or in a recently landed immigrant from an endemic area presenting with symptoms of acute hepatitis. As Canadians are more

\section{REFERENCES}

1. Wong DC, Purcell RH, Sreenivasan MA, Prasad SR, Pavri KM. Epidemic and endemic hepatitis in India: evidence for non-A non-B virus etiology. Lancet 1980;ii:876-9.

2. Krawczynski K, Bradley DW. Enterically transmitted non-A non- $B$ hepatitis: identification of virus associated antigen in experimentally infected cynomolgus macaques. J Infect Dis 1989;159:1042-9.

3. Bradley DW, Andiaparidze A, Cook EH, et al. Etiological agent of enterically transmitted non-A non-B hepatitis.

J Gen Virol 1988;69:731-8.

4. Reyes GR, Purdy MA, Jim JP, et al. Molecular cloning of a cDNA from the virus responsible for enterically transmitted non-A non-B hepatitis. Science 1990;247:1335-9.

5. Craske $J$. Hepatitis $C$ and non-A non-B hepatitis revisited: hepatitis E, F and G. J Infect 1992;25:243-50.

6. Anankalle VA, Chobe LP, Jha J, et al. Aetiology of acute sporadic non-A non-B viral hepatitis in India. J Med Virol 1993;40:121-5.

7. Naik SR, Aggarwal R, Salunke PN. A large waterborne viral hepatitis E epidemic in Kanpur India. Bull World Health Organ 1992;70:597-604.

8. Ranjit R, Aggarwal R. Hepatitis E virus genome in stool of hepatitis patients during large epidemic in north India. Lancet 1991;338:783-4.

9. Skidmore SJ, Yarbough PO, Gabor KA, et al. Hepatitis E virus: the cause of a water borne hepatitis outbreak. and more often travelling to exotic destinations, physicians in this country should be aware of the existence of hepatitis $E$, which is likely underreported. It is worth noting that, since March 1994, hepatitis E serology has been available for selected cases at the Laboratory Centre for Disease Control in Ottawa.

ACKNOWLEDGEMENTS: We thank Dr Steve Lambert at the Centers for Disease Control and Prevention for his collaboration.

J Med Virol 1992;37:58-60.

10. Thomas D, Mahley R, Badur S. Epidemiology of hepatitis E virus infection in Turkey. Lancet 1993;341:1561-2.

11. Tsega E, Hanson B, Krawczynski K. Acute sporadic viral hepatitis in Ethiopia: causes, risk factors and effects on pregnancy. Clin Infect Dis 1992;14:961-5.

12. Hyams K, Purdy M, Kaur M. Acute sporadic hepatitis $E$ in Sudanese children: analysis based on a new Western blot. J Infect Dis 1992:165:1001-5.

13. Goldsmith R, Yarbough P, Reyes G. EIA assay for diagnosis of acute sporadic hepatitis $E$ in Egyptian children. Lancet 1992;339:328-31.

14. Rioche M, Himmich $\mathrm{H}$, Cherkaoui A. Forte incidence des hepatitis non-A non-B sporadiques au Maroc: étude epidemiologique. Bull Soc Pathol Exot 1991:84:117-27.

15. Roberts JK, Whitlock RT. Hepatitis E in a traveler to Bangladesh. Ann Intern Med 1992;117:93. (Lett)

16. Zhuang $\mathrm{H}$, Cao $\mathrm{XY}$, Lui $\mathrm{CB}$, Wang GM. Enterically transmitted non-A non-B hepatitis in China. In: Shihata T, Purcell RH, Vahida T, eds. Viral Hepatitis C, D, E. Amsterdam: Elsevier Science Publishing Co Inc, 1991:277-85.

17. Favorov MO, Fields HA, Purdy TL, et al. Serologic identification of hepatitis $E$ virus infection in epidemic and endemic settings. $J$ Med Virol 1992;36:246-50.

18. Velazquez $\mathrm{O}$, Stetler HC, Avila $\mathrm{C}$, et al. Epidemic transmission of enterically transmitted non-A non-B hepatitis in Mexico. JAMA 1990;263:3281-5. 
19. Pillot J, Lazizi $Y$, Diallo $Y$. Frequent sporadic hepatitis $E$ in West Africa evidenced by characterization of a virus associated antigen in the stool. J Hepatol 1992;15:420-1. (Lett)

20. Hepatitis E among US travelers, 1989-92. MMWR 1993;42:1-4

21. Skidmore SJ, Yarbough $P$, Gabor K, et al. Imported hepatitis E in the UK. Lancet 1991;337:1541.

22. Zaaiger HL, Kok M, Lelie PN, et al. Hepatitis $E$ in the Netherlands: imported and endemic. Lancet 1993;341:826. (Lett)

23. Jardi R, Buti M, Rodriguez-Frias $F$, et al. Hepatitis $E$ infection in acute sporadic hepatitis in Spain. Lancet 1993:341:1355-6. (Lett)

24. Chaudan A, Jameel S, Dilawari J, et al. Hepatitis E virus transmission to a volunteer. Lancet 1993;341:149-50.
25. Mahony J, Chernesky M. Vertical transmission of viral hepatitis. Transfus Med Rev 1993;7:112-20.

26. Khuroo MS, Dar MY. Hepatitis E: evidence for person to person transmission and inability of low dose immune serum globulin from an Indian source to prevent it. Indian J Gastroenterol 1992;11:113-6.

27. Yarbough $P$. Hepatitis E: diagnosis of infection. Clin Microbiol Newsletter 1993;15.

28. Mishra L, Seeff LB. Viral hepatitis A through E complicating pregnancy. Gastroenterol Clin North Am 1992;21:873-87.

29. Lok A, Kwan W, Moeckli R, et al. Seroepidemiological survey of hepatitis $E$ in Hong Kong by recombinant based EIA. Lancet 1992;340:1205-8. 


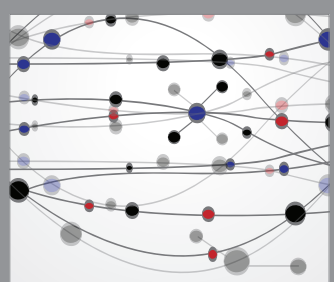

The Scientific World Journal
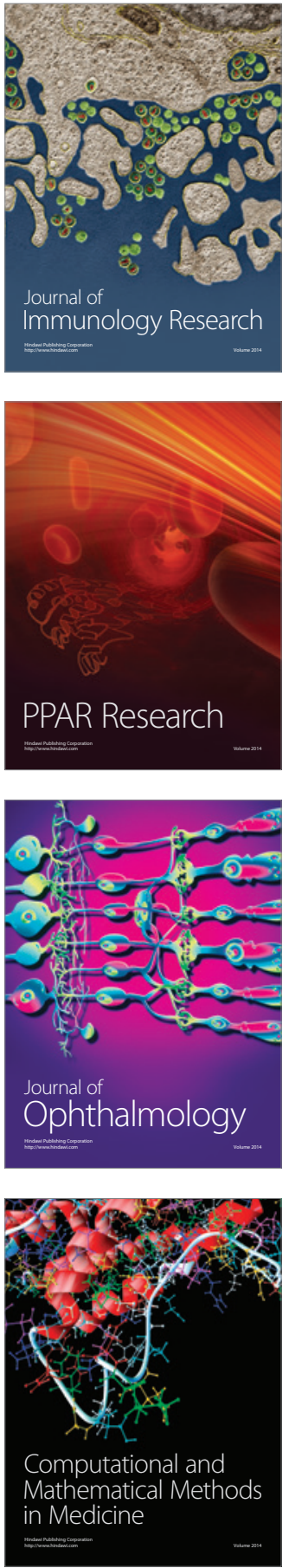

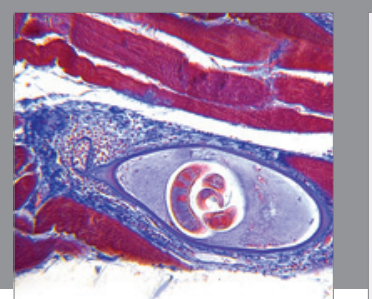

Gastroenterology Research and Practice

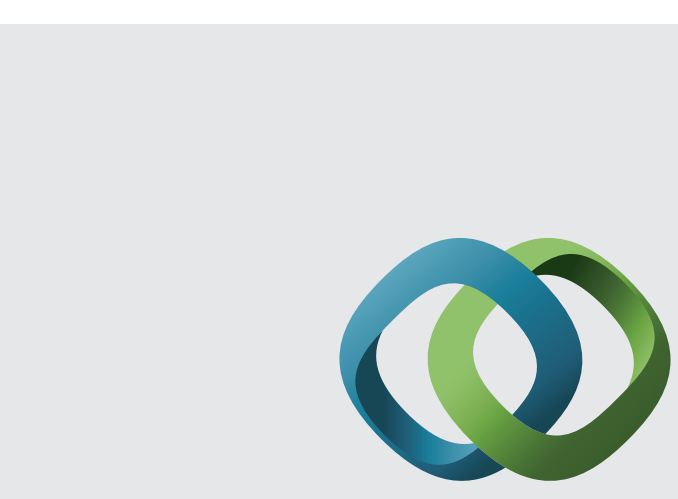

\section{Hindawi}

Submit your manuscripts at

http://www.hindawi.com
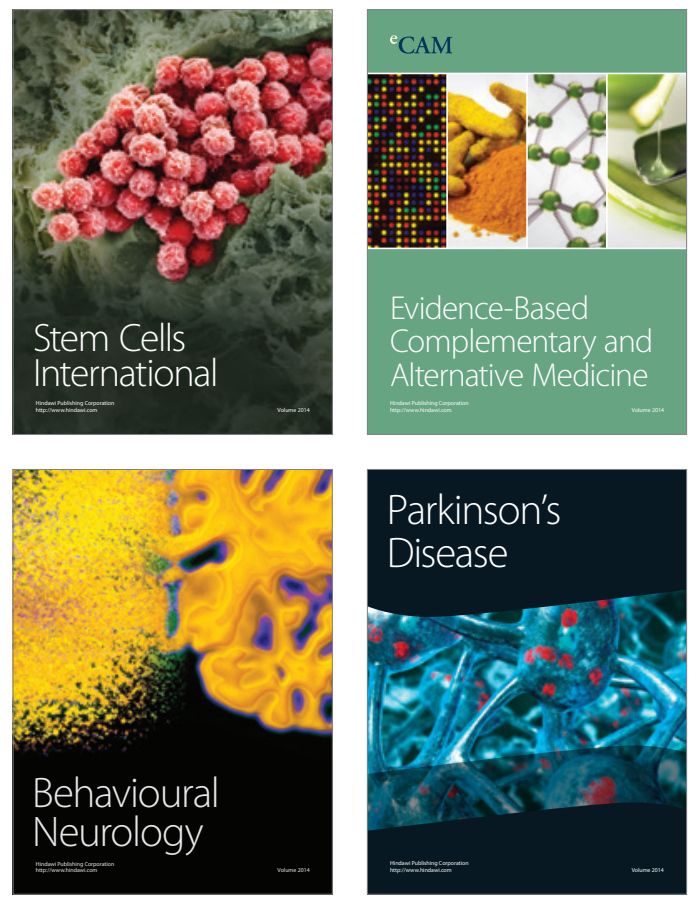
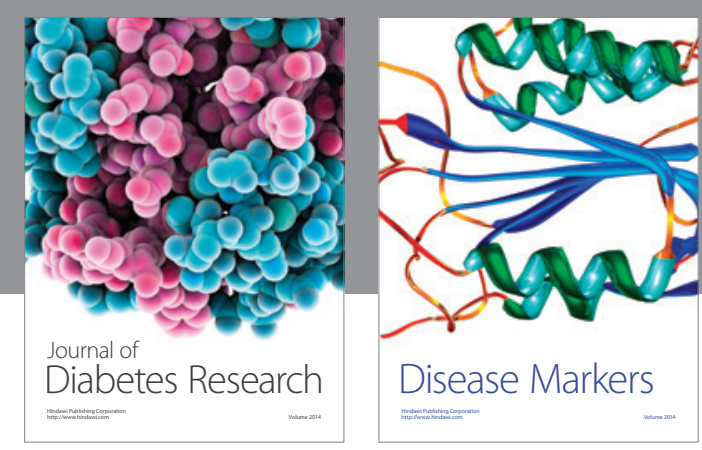

Disease Markers
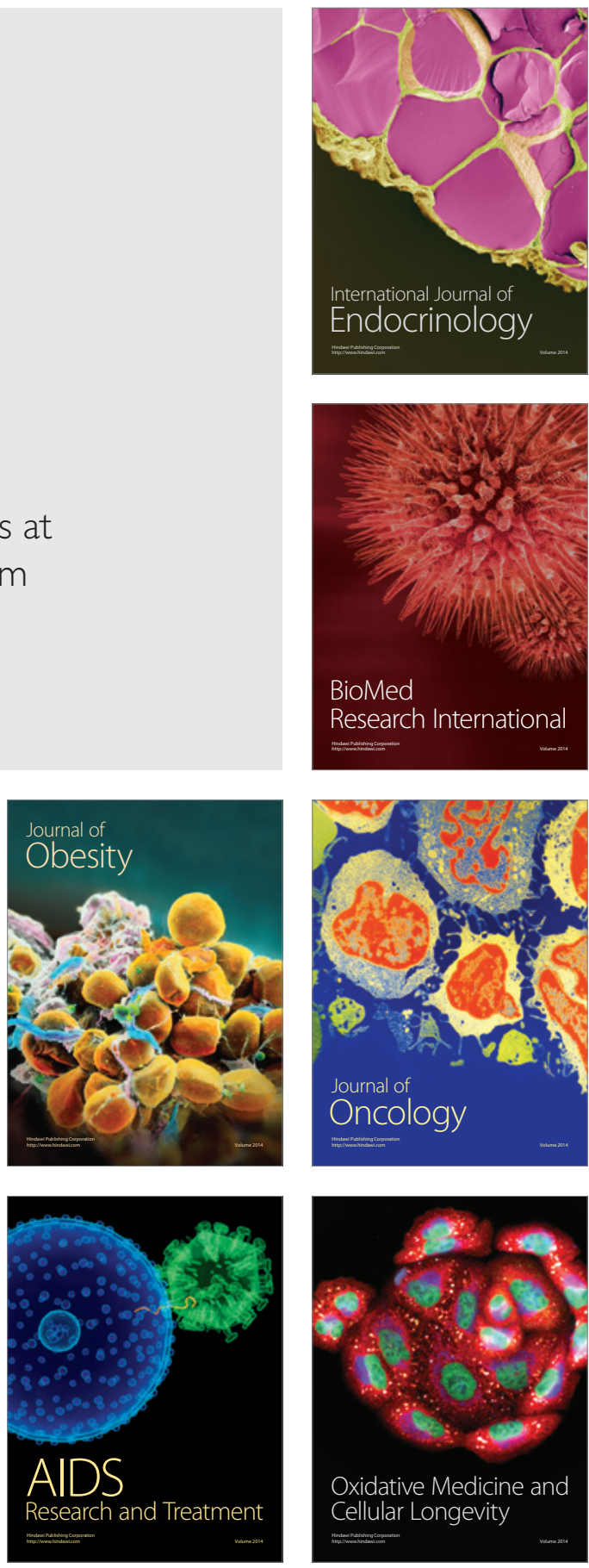